\title{
Evaluation of the Difference in Body Composition of Thai Native Cattle and Swamp Buffaloes from that of Holstein Cattle in Northeast Thailand Using Urea Space
}

\author{
Itoko NONAKA ${ }^{1 *}$, Arata KOGA ${ }^{2}$, Masaharu ODAI ${ }^{3,5}$, \\ Rumphrai NARMSLIEE ${ }^{4}$ and Fuminori TERADA ${ }^{1}$ \\ ${ }^{1}$ Department of Animal Physiology and Nutrition, National Institute of Livestock and Grassland \\ Science (Tsukuba, Ibaraki 305-0901, Japan) \\ ${ }^{2}$ Institute of Agriculture and Forestry, University of Tsukuba (Tsukuba, Ibaraki 305-8572, Japan) \\ ${ }^{3}$ Animal Production and Grassland Division, Japan International Research Center for Agricultural \\ Sciences (JIRCAS) (Tsukuba, Ibaraki 305-8686, Japan) \\ ${ }^{4}$ Khon Kaen Animal Nutrition Research and Development Center (Thapra, Maung, Khon Kaen, \\ 40260, Thailand)
}

\begin{abstract}
Four female Holstein cattle (Holstein, average body weight (BW) $359 \mathrm{~kg}$ ), four castrated male native cattle (Native, $257 \mathrm{~kg}$ ) and four castrated male swamp buffaloes (Buffalo, $543 \mathrm{~kg}$ ) were subjected to urea space measurements to determine body composition of the different animals and to investigate the effect of $48 \mathrm{~h}$ of water deprivation on the change of body composition in Northeast Thailand. The percentage of empty body protein (EBPRO) compared to empty body weight (EBW) was similar among Holstein, Native and Buffalo. The percentage of empty body water $\left(\mathrm{EBH}_{2} \mathrm{O}\right)$ was the highest in Native, while the percentage of empty body fat (EBFAT) was the highest in Buffalo. After the dehydration, mean BW decreased in Holstein, Native and Buffalo, and not only water but also protein and fat were mobilized. The percentage of EBPRO was similar among Holstein, Native and Buffalo; however, the percentage of EBFAT was the highest in Buffalo and the percentage of $\mathrm{EBH}_{2} \mathrm{O}$ was the highest in Native. After dehydration, the percentage of EBFAT decreased and the percentage of $\mathrm{EBH}_{2} \mathrm{O}$ increased in all animals.
\end{abstract}

Discipline: Animal industry

Additional key words: dehydration

\section{Introduction}

There are many large ruminants raised in Northeast Thailand, i.e., 2.5 million and 2.2 million heads of cattle and swamp buffaloes, respectively ${ }^{4}$. The establishment of a proper feeding management system for ruminants has been urged for the sustainable development of animal production. Thai native cattle (Bos indicus) and swamp buffaloes have adapted genetically to local conditions, disease, available feed, climate, predators, and many other persistent variables imposed by the local environment. Because the nutrient requirements differ quite widely among Thai native cattle, swamp buffaloes and Holstein cattle, clarifying the nutrient requirements of ruminants is necessary for adequate feeding management.

According to Devendra ${ }^{5}$, the bulk of evidence suggests that the swamp buffalo probably has an inherent capacity to utilize dietary fiber relatively more effi-

Mr. Masaharu ODAI carried out the project entitled "Improvement of Dairy Cattle Production with Locally Available Feed Resources in Northeast Thailand" in collaboration with Khon Kaen Animal Nutrition Research and Development Center (KKANRDC) for seven years from July 1994. The project has been involved in the Comprehensive Research Project entitled "Sustainable Agricultural Systems in Northeast Thailand", which was implemented by JIRCAS in 1995, in collaboration with the Thai Research Organization. Present address:

${ }^{5}$ Department of Planning and General Administration, National Institute of Livestock and Grassland Science

(Tsukuba, Ibaraki 305-0901, Japan)

*Corresponding author: fax +81-29-838-8606; e-mail witoko69@affrc.go.jp

Received 27 October 2005; accepted 10 February 2006. 
ciently than cattle can do. Although the Thai native cattle are considered to have an ability to utilize low-quality feed, we have little information about them, in Southeast Asia.

Energy and protein requirements can be proved by digestion and metabolism trials, but those trials require considerable labor and expensive equipment. Body composition, especially the amount of energy reserve, is considered to reflect an animal's energy balance, and measuring changes in body composition (water, fat and protein) is one way to clarify the differences in nutrient requirements. Indirect and noninvasive techniques provide a method that is repeatable to describe body composition of livestock. Dilution techniques for estimating body water have been in general use for many years. Measurement of tritium and deuterium is another method for determining body composition. Tritium or deuterium spread evenly and rapidly and are not toxic; they result in no deleterious physiologic effect and are not selectively stored $^{1,10}$. Measurements of body water or of tritium and deuterium are unsuitable for field experiments, because they require several days to determine body water turnover rate, and persons using the techniques need special equipment to analyze the tritium and deuterium ${ }^{2}$. The urea dilution technique is a reliable and practical method for analyzing the kinetics of body water, protein and $\mathrm{fat}^{8}$, because urea is inexpensive and the technique needs only $12 \mathrm{~min}$

There is little information available about body composition of Thai native cattle and buffaloes. The objective of this study was, firstly, to evaluate the difference of body composition among Holstein cattle, Thai native cattle and swamp buffaloes using the urea dilution technique in Thailand. Additionally, we attempted to clarify the effect of $48 \mathrm{~h}$ of water deprivation on the change of body composition.

\section{Materials and methods}

The experiment was conducted at the Khon Kaen Animal Nutrition Research and Development Center (KKANRDC), Khon Kaen, Thailand. Four female Holstein cattle (Holstein, average body weight $359 \pm 14 \mathrm{~kg}, 6$ years old), four castrated male Thai native cattle (Native, $257 \pm 13 \mathrm{~kg}, 4$ years old) and four castrated male swamp buffaloes (Buffalo, $543 \pm 32 \mathrm{~kg}, 7$ years old) were used in this study. The Holstein cattle were multiparous, not pregnant and not lactating. After a 10-day preliminary period, the experiment lasted 3 days, consisting of a 1day control period followed by 2 days of water deprivation. Each animal was allocated an individual pen during the experiment. Rice straw was fed throughout the experiment. The body weight of each animal was measured twice, before and after the dehydration.

\section{Urea space measurement}

Composition of water, fat and protein in the body was estimated from urea space procedures as described by Preston and Koch ${ }^{11}$. Animals were fitted with jugular catheters ( $0.9 \mathrm{~m}$ length, 16 gauge o.d.) immediately prior to urea infusion. The first urea space measurement was conducted from 14:00 to $16: 00$ just before dehydration, and the second measurement was conducted from 14:00 to 16:00 after 2 days of dehydration. Catheters were flushed with heparin $(20 \mathrm{IU} / \mathrm{mL})$ in physiological saline $(9 \mathrm{~g} / \mathrm{L}$ of $\mathrm{NaCl})$ and kept capped overnight with $100 \mathrm{IU} /$ $\mathrm{mL}$ of heparin in physiological saline. A $10-\mathrm{mL}$ blood sample was drawn into a heparinized tube before urea infusion to determine the baseline values of urea. Approximately $130 \mathrm{mg}$ of urea/ $\mathrm{kg} \mathrm{BW}$ in a solution of $200 \mathrm{~g} / \mathrm{L}$ of sterile saline was infused over $2.5 \mathrm{~min}$. Time was recorded at the start and end of infusion. The catheter was then flushed with $10 \mathrm{~mL}$ of heparinized saline. The cylinder containing the urea solution was weighed to the nearest $0.1 \mathrm{~g}$ before and after infusion to determine gravimetrically the dose of urea. A $10-\mathrm{mL}$ blood sample was drawn from the jugular catheter up to 12 min following the midpoint of infusion. Urea space measurements for each animal were determined before and after dehydration. Blood was kept on ice and then centrifuged, and plasma was decanted and frozen at $-10^{\circ} \mathrm{C}$ until analysis. Urea nitrogen in plasma was analyzed using diagnostic kits (Biotech Reagent, Thailand) based on the enzymecalorimetric method.

Urea space (US) was determined by the change in plasma urea nitrogen concentration before and $12 \mathrm{~min}$ after the midpoint of an intravenous infusion of urea. US was calculated by the following equation: US $(\mathrm{kg})=$ [dose of urea $\mathrm{N}(\mathrm{mg} / 100 \mathrm{~mL})$ ] / [change in plasma urea $(\mathrm{mg} / 100 \mathrm{~mL}) \times 10]$. Empty body components also were expressed as a percentage of full-fed BW (live weight; US\%EB). Empty body water $\left(\mathrm{EBH}_{2} \mathrm{O}\right)$, empty body protein (EBPRO) and empty body fat (EBFAT) were estimated by the following equations: $\mathrm{EBH}_{2} \mathrm{O}=20.6+0.93$ US, EBPRO $=-1.2+0.31$ US, EBFAT $=-19.8+0.30$ US $^{6}$. Empty body weight (EBW) was estimated by assuming that empty body ash was $5 \%{ }^{12}$; EBW = $\left(\mathrm{EBH}_{2} \mathrm{O}+\mathrm{EBPRO}+\right.$ EBFAT $) / 95 \times 100$. The rate of decreased body composition was calculated by the equation; the rate of decreased empty body composition $(\%)=$ (empty body composition before dehydration - empty body composition after dehydration) / empty body composition before dehydration. 
A general linear model ${ }^{14}$ was used to analyze the effects of animal species and dehydration. The significant difference among animals was determined using an F-test.

\section{Results and discussion}

\section{The differences of body composition among Holstein cattle, Thai native cattle and swamp buffaloes before dehydration}

Our experiment was conducted in February 2001, the mean environmental temperature was $23.1^{\circ} \mathrm{C}$ (the range was from 17.3 to $30.6^{\circ} \mathrm{C}$ ), and the mean environmental relative humidity was $61.8 \%$. The empty body composition (water, protein and fat) of animals before dehydration is shown in Table 1. Before dehydration, the percentage of EBPRO compared to empty body weight was similar among Holstein, Native and Buffalo (18.7, 18.6 and $18.8 \%$, respectively). The percentage of $\mathrm{EBH}_{2} \mathrm{O}$ was the highest in Native (Holstein, Native and Buffalo; 65.8, 68.1 and 63.2\%, respectively), while the percentage of EBFAT was the highest in Buffalo (Hol- stein, Native and Buffalo; 10.6, 8.4 and $13.1 \%$, respectively).

There was no data for body composition of Thai native cattle or swamp buffaloes available; however, there was some data for that of Holstein cattle, and so we have attempted here to compare the body composition of Holstein cattle with those of established data. Hammond et al. ${ }^{6}$ reported the percentage body composition of Holstein steers from a slaughter-balance trial. They demonstrated that means (and ranges, minimum to maximum) for body weight and percentages of $\mathrm{EBH}_{2} \mathrm{O}, \mathrm{EBPRO}$ and EBFAT were $300.0 \mathrm{~kg}$ (143.0 to $404.0 \mathrm{~kg}$ ), $66.1 \%$ (62.0 to $72.9 \%$ ), $18.5 \%$ (16.6 to $19.5 \%$ ), and $10.1 \%$ (5.4 to $14.3 \%)$, respectively. Velazco et al. ${ }^{16}$ examined carcass proportions of Holstein steers at 3, 6, 9, and 12 months of age. The means (and ranges) for body weight and percentages of $\mathrm{EBH}_{2} \mathrm{O}, \mathrm{EBPRO}$ and EBFAT were $281.2 \mathrm{~kg}$ ( 99.8 to $464.7 \mathrm{~kg}$ ), $66.4 \%$ (57.8 to $75.8 \%$ ), $19.0 \%$ (16.9 to $20.7 \%$ ), and $13.8 \%$ (2.6 to $24.6 \%$ ), respectively. Our results for the percentage of $\mathrm{EBH}_{2} \mathrm{O}$, EBPRO, and EBFAT (18.7, 65.8 and 10.6\%, respectively) of female Holstein did not differ from their carcass proportion data.

Table 1. Empty body composition of animals before and after dehydration

\begin{tabular}{|c|c|c|c|c|c|}
\hline & Holstein & Native & Buffalo & $\mathrm{SE}$ & Probability \\
\hline \multicolumn{6}{|l|}{ Before dehydration } \\
\hline Body weight (kg) & $359.0^{\mathrm{b}}$ & $257.5^{\mathrm{c}}$ & $550.0^{\mathrm{a}}$ & 23.6 & 0.0003 \\
\hline \multicolumn{6}{|l|}{ Weight (kg) } \\
\hline $\mathrm{EBH}_{2} \mathrm{O}$ & $163.7^{\mathrm{b}}$ & $132.5^{\mathrm{c}}$ & $230.8^{\mathrm{a}}$ & 8.6 & 0.0005 \\
\hline EBPRO & $46.5^{\mathrm{b}}$ & $36.1^{\mathrm{c}}$ & $68.9^{\mathrm{a}}$ & 2.9 & 0.0005 \\
\hline EBFAT & $26.4^{\mathrm{b}}$ & $16.3^{\mathrm{c}}$ & $48.0^{\mathrm{a}}$ & 2.8 & 0.0005 \\
\hline EBW & $249.0^{\mathrm{b}}$ & $194.7^{\mathrm{c}}$ & $366.0^{\mathrm{a}}$ & 15.0 & 0.0005 \\
\hline \multicolumn{6}{|l|}{ Rate of EBW (\%) } \\
\hline $\mathrm{EBH}_{2} \mathrm{O}$ & $65.8^{\mathrm{b}}$ & $68.1^{\mathrm{a}}$ & $63.2^{\mathrm{c}}$ & 0.3 & 0.0001 \\
\hline EBPRO & $18.7^{\mathrm{b}}$ & $18.6^{\mathrm{c}}$ & $18.8^{\mathrm{a}}$ & 0.0 & 0.0012 \\
\hline EBFAT & $10.6^{\mathrm{b}}$ & $8.4^{\mathrm{c}}$ & $13.1^{\mathrm{a}}$ & 0.3 & 0.0001 \\
\hline \multicolumn{6}{|l|}{ After dehydration } \\
\hline Body weight (kg) & $321.8^{\mathrm{b}}$ & $234.8^{\mathrm{c}}$ & $487.3^{\mathrm{a}}$ & 23.7 & 0.0008 \\
\hline \multicolumn{6}{|l|}{ Weight (kg) } \\
\hline $\mathrm{EBH}_{2} \mathrm{O}$ & $145.4^{\mathrm{b}}$ & $116.2^{\mathrm{c}}$ & $195.5^{\mathrm{a}}$ & 6.5 & 0.0016 \\
\hline EBPRO & $40.4^{\mathrm{b}}$ & $30.7^{\mathrm{c}}$ & $57.1^{\mathrm{a}}$ & 2.2 & 0.0005 \\
\hline EBFAT & $20.5^{\mathrm{b}}$ & $11.0^{\mathrm{c}}$ & $36.6^{\mathrm{a}}$ & 2.1 & 0.0005 \\
\hline EBW & $217.1^{\mathrm{b}}$ & $166.2^{\mathrm{c}}$ & $308.8^{\mathrm{a}}$ & 13.8 & 0.0016 \\
\hline \multicolumn{6}{|l|}{ Rate of EBW (\%) } \\
\hline $\mathrm{EBH}_{2} \mathrm{O}$ & $67.0^{\mathrm{b}}$ & $70.0^{\mathrm{a}}$ & $64.4^{\mathrm{c}}$ & 0.4 & 0.0013 \\
\hline EBPRO & $18.6^{\mathrm{b}}$ & $18.5^{\mathrm{c}}$ & $18.8^{\mathrm{a}}$ & 0.0 & 0.0016 \\
\hline EBFAT & $9.4^{\mathrm{b}}$ & $6.6^{\mathrm{c}}$ & $11.8^{\mathrm{a}}$ & 0.4 & 0.0013 \\
\hline
\end{tabular}

$\mathrm{EBH}_{2} \mathrm{O}$ : Empty body water. EBPRO: Empty body protein. EBFAT: Empty body fat. EBW: Empty body weight. $a, b, c$ : Means in the same row with different superscripts differ $(\mathrm{P}<0.05)$. 

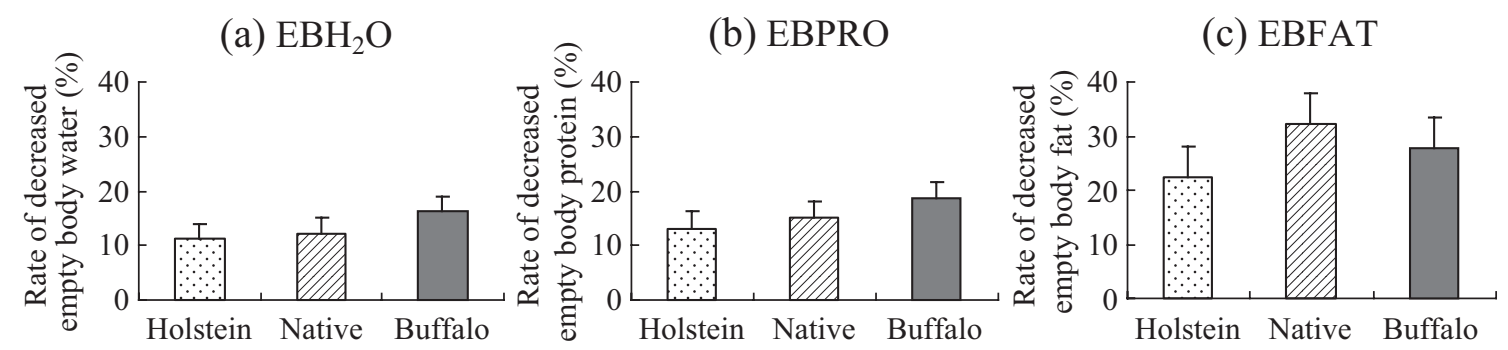

Fig. 1. The changes of empty body composition by dehydration Means and SE. (a) $\mathrm{EBH}_{2} \mathrm{O}$ : Empty body water, (b) EBPRO: Empty body protein, (c) EBFAT: Empty body fat.

Reid et al. ${ }^{12}$ presented that the proportional relationships among body components of beef and dairy cattle do not differ. Wells and Preston ${ }^{17}$ also indicated that there were no differences observed using the general breed type specification of Bos indicus L. cross and Bos taurus L. cross steers for empty carcass fat, and that beef cattle of different breed types may be accurately evaluated with urea dilution. In this study, we used the prediction equations made by Hammond et al. ${ }^{6}$. The estimates of body composition in each animal of this study generally agreed with the results of others ${ }^{6,12,15}$.

Our results indicated that differences may not be due to the difference of animal species, but due to their mature size or sex. Chantalakhana ${ }^{3}$ reported that the mature body weight of swamp buffaloes in Thailand was from 404 to $600 \mathrm{~kg}$. On the other hand, the mature body weight of Thai native male cattle was not clear, though the average mature weight of Bos indicus L. is about 450 $\mathrm{kg}^{13}$. Additionally, the mature weight of small breed Holstein female cattle is about $450 \mathrm{~kg}^{9}$. Therefore, the buffaloes we studied were considered to be mature, while the native and Holstein cattle in our study had not reached mature weight. Because the percentage of $\mathrm{EBH}_{2} \mathrm{O}$ is higher and the percentage of EBFAT is lower in young animals, the percentage of EBFAT in Buffalo was higher than in Native and Holstein in this study.

\section{The effects of dehydration on body composition among Holstein cattle, Thai native cattle and swamp buffaloes}

The empty body composition (water, protein and fat) of animals after dehydration is shown in Table 1. The percentage of EBPRO was similar among Holstein, Native and Buffalo (18.6, 18.5 and 18.8\%, respectively); however, the percentage of EBFAT $(9.4,6.6$ and $11.8 \%$, respectively) decreased instead of $\mathrm{EBH}_{2} \mathrm{O}(67.0,70.0$ and $64.4 \%$, respectively) increasing in all animals (Table 1).

The changes of empty body composition by dehy- dration are shown in Fig. 1. After 2 days of dehydration, mean BW decreased in Holstein, Native and Buffalo $(37.8,22.8$ and $63.0 \mathrm{~kg}$, respectively). The rate of decreased empty body water, protein and fat were not different among Holstein, Native and Buffalo, however, not only water but also protein and fat were mobilized in all animals. It is considered that the changes of EBPRO and EBFAT indicate mobilization of body tissue, and that they reflect nutrient balance of each animal. According to Devendra ${ }^{5}$, the swamp buffalo probably has an inherent capacity to utilize dietary fiber relatively more efficiently than cattle can. Kawashima et al. $^{7}$ reported also that the digestibility of fiber and utilization of energy tended to be higher in buffaloes than in cattle when lowquality roughage was given. However, the mobilized rate of protein and fat to empty body weight was not different in each animal; it could not clarify the difference of nutrient balance among animal species. The mobilized weight of $\mathrm{EBH}_{2} \mathrm{O}$ was about 3 times that of EBPRO or EBFAT in each animal. The percentage of mobilization was higher in EBFAT than that in EBPRO, which suggested that it was faster to mobilize body fat than body protein.

\section{Conclusion}

From this study, it could be concluded that the urea dilution technique is a simple and reliable method and that the technique could provide useful information about body composition of ruminants in Southeast Asia. Before dehydration, the percentage of EBPRO was similar among animals. The percentage of $\mathrm{EBH}_{2} \mathrm{O}$ was the highest in Thai native cattle, while that of EBFAT was the highest in buffalo. However, the differences may not be due to the difference of animal species, but rather to their age or sex. The $48 \mathrm{~h}$ of water deprivation affected the mobilization of body fat and protein, but there was no significant difference among animal species in the change of empty body composition. 


\section{References}

1. Byers, F. M. (1979a) Measurement of protein fat accretion in growing beef cattle through isotope dilution procedures. Ohio Agr. Res. Dev. Cent., Beef Cattle Res. Rep., Anim. Sci. Ser., 79-1, 36-47.

2. Byers, F. M. (1979b) Extraction and measurement of deuterium oxide at tracer levels in biological fluids. Anal. Biochem., 98, 208-213.

3. Chantalakhana, C. (1992) Genetics and breeding of swamp buffaloes. In Buffalo production, productionsystem approach. World animal science C6, eds. Tulloh, N. M. \& Holmes, J. H. G., Elsevier, Amsterdam, 95-104.

4. Department of Livestock Development (1996) Yearly statistics reports. Ministry of Agriculture and Cooperatives, Thailand.

5. Devendra, C. (1992) Nutrition of swamp buffaloes. In Buffalo production, production-system approach. World animal science C6, eds. Tulloh, N. M. \& Holmes, J. H. G., Elsevier, Amsterdam, 135-151.

6. Hammond, A. C., Waldo, D. R. \& Rumsey, T. S. (1990) Prediction of body composition in Holstein steers using urea space. J. Dairy Sci., 73, 3141-3145.

7. Kawashima, T. et al. (2000) Comparative study on energy and nitrogen metabolisms between Brahman cattle and swamp buffalo fed with low quality diet. In Improvement of cattle production with locally available feed resources in Northeast Thailand, ed. Kawashima, T., JIRCAS, Tsukuba, Japan, 116-122.

8. Kock, S. W. \& Preston, R. L. (1979) Estimation of bovine carcass composition by the urea dilution technique. $J$.
Anim. Sci., 48, 319-327.

9. National Research Council (2001) Nutrient requirements of dairy cattle, 7th revised edition. National Academy Press, Washington, D.C., USA, 278.

10. Odwongo, W. O. et al. (1985) Measurement of water kinetics with deuterium oxide in lactating dairy cows. $J$. Dairy Sci., 68, 1155-1164.

11. Preston, R. L. \& Koch, S. W. (1973) In vivo prediction of body composition in cattle from urea space measurements. Proc. Soc. Exp. Biol. Med., 143, 1057-1061.

12. Reid, J. T., Wellington, G. H. \& Dunn, H. O. (1955) Some relationships among the major chemical components of the bovine body and their application to nutritional investigations. J. Dairy Sci., 12, 1344-1359.

13. Robelin, J. \& Tulloh, N. M. (1992) Patterns of growth of cattle. In Beef cattle production, production-system approach. World animal science C5, eds. Jarrige, R. \& Béranger, C., Elsevier, Amsterdam, 111-129.

14. SAS Institute Inc. (1994) SAS/STAT ${ }^{\circledR}$ User's guide, release 6.03 edition. SAS Institute Inc., Cary, NC, USA.

15. Tomlinson, D. L. et al. (1997) Influence of undegradability of protein in the diet on intake, daily gain, feed efficiency, and body composition of Holstein heifers. $J$. Dairy Sci., 80, 943-948.

16. Velazco, J. et al. (1997) The use of urea dilution for estimation of carcass composition of Holstein steers at 3,6, 9, and 12 months age. J. Anim. Sci., 75, 139-147.

17. Wells, R. S. \& Preston, R. L. (1998) Effects of repeated urea dilution measurement on feedlot performance and consistency of estimated body composition in steers of different breed types. J. Anim. Sci., 76, 2799-2804. 